\title{
Teaching the Reasons Why: An Analysis of Causation in History Textbooks and Historical Primary Source Documents
}

\author{
Jason C. Fitzgerald \\ Department of Education, Wagner College, USA
}

Copyright $\mathrm{C} 2019$ by authors, all rights reserved. Authors agree that this article remains permanently open access under the terms of the Creative Commons Attribution License 4.0 International License

\begin{abstract}
The variety of primary source documents (PSDs) used in secondary education history classes leads to students' assorted exposure to key language constructions important to historical reading and writing such as causal expression. This study asks (1) what is the difference in causal construction exposure between PSDs and textbooks and (2) in what ways do the types of causation qualitatively vary between textbooks and primary source documents. Quantitative analysis demonstrates that students are exposed to a statistically higher rate of causal constructions when reading textbooks then when they read PSDs. Qualitative analysis illustrates that the language used to construct causation in the PSDs was different from that found in the history textbooks. These findings indicate that PSDs do not mentor students in the types of historical writing constructions used in historical explanation.
\end{abstract}

Keywords Causation, History Education, Textbooks, Primary Source Documents, Historical Thinking

\section{Introduction}

Over the last two decades, social studies instructional practice in the United States has shifted away from using the traditional history textbook as a primary instructional material towards using primary source documents (PSDs). In addition to factors of cost and the digitization of instructional materials, this shift has occurred because of the widespread criticisms against "textbook narratives" [e.g., 1-4] and the rise of historical thinking pedagogy [e.g., 5-8]. Today, approximately two-thirds of social studies teachers in the United States choose to engage students in reading historical primary source documents instead of traditional history textbooks [9].

One result of reduced textbook usage is a reduction in students' exposure to those same textbooks as mentor texts, no matter how poorly written they may be. Mentor texts model the content and discourse structures of the discipline $[10,11]$. They are used to socialize students to both the "recognition rules" (what meanings can be legitimately connected to each other) and the "realization rules" (how meanings can be legitimately expressed) of a discipline [12]. Despite its failings, the history textbook has served as the mentor text for classrooms in the United States for more than a century [13]. Limiting textbook use in the history classroom with no replacement text limits students' exposure to such socialization.

To be sure, students can be socialized in the recognition and realization rules of history via other classroom texts. Teachers' instructional explanations, for example, contribute to students' understandings of decontextualized, disciplinary-specific language when teachers pack and unpack semantically dense content [14,15]. While instructional explanations may not have the sustained, uninterrupted features of a written text (because teaching is filled with multiple intentional and unintentional interruptions), students are still exposed to what can be said of a historical topic and how it can be said. In other words, the content and lexicogrammar of history (the recognition and realization rules) are demonstrated to some degree within a strong instructional explanation.

In addition to instructional explanations, the primary source documents (PSDs) themselves can instruct students in content and lexicogrammar. The PSDs can display the content vocabulary and lexicogrammar one might expect to see in students' history production (writing and speaking). Indeed, teachers require students to cite from these texts, recasting language from PSDs into their own historical explanations and arguments. Thus, while history classrooms may be limiting students' exposure to the history textbook as a mentor text, other texts potentially mentor students' historical production.

Of the lexicogrammatical features that students need to learn from these texts, time and cause are the most critical [16]. These features produce and legitimize historical 
argumentation [17]. This study explores one of these features, causation, in documents included in a widely used PSD curriculum, detailing the extent to which students are exposed to various types of causal constructions, exposure from which students might enact the realization rules of history. These constructions are then compared with those found in popular history textbooks, exploring differences in students' exposure and their potential abilities to construct history in disciplinarily appropriate ways.

\subsection{Inclusion of Primary Source Documents in History Education}

For more than a century, the idea of teaching history through the use of primary sources has been contested in the United States. On the one hand, early councils on primary and secondary education supported the practice as a way to prepare students to think "logically" $[18,19]$, what we might conclude today to mean historically.

Such engagement with "real" documents was later supported by the Progressives in an effort to problematize history and current events, supporting the primary aim of the social studies to prepare citizens [20]. On the other hand, these attempts to problematize the historical narrative consistently encountered criticism from those who preferred a more unified historical narrative [21].

When the study of history education was reconstituted in psychological rather than historical or nationalistic terms with Wineburg's[22,23] historical thinking work, curricula based on historical primary source documentation gained traction. Rather than focusing on the duel between those supporting problematized history education and those supporting heritage education, a psychological approach presented a third way of engaging the conversation by focusing on how historians think rather than "correct" narrative(s). Historical thinking became a frame of reference for social studies curriculum standards and development [24-26].

Recent research explores how students read, write, and do history [e.g., 27-30]. Much of this work has focused on helping teachers and teacher candidates to explore the "unnatural" process of history-making with their students, which involves situating oneself in another time and place while minimizing presentism.

At the core of this research, the shift from textbooks to primary sources has been viewed as a net good for history education. A few studies have explored the relationships between historical primary source texts and students' writing from a genre perspective [e.g., 31,32]. Little history education research explores what has been gained or lost from this shift.

\subsection{The Value of Causal Recasting}

Fortunately, research by educational linguists has made history one of the most well-researched school subjects from a social semiotic perspective [33]. There is extensive research on macro-structures of valued historical genres [e.g., 34-36], the kinds of knowledge structures valued in those genres [e.g., 37,38], and the role of lexicogrammatical features in expressing causation and temporality [39-41]. Through such work, researchers have detailed the ways in which the language of history shifts and matures from "everyday language" to academic discourse [42].

One key feature in this shift is the recasting of causation. Traditionally, cause/effect has been taught via identification of causal signals such as because, so, and thus $[43,44]$. In addition to these signals, mature historical argumentation relies on causal constructions that are "hidden" inside the clause, negating the need for the frequent use of causal connectors [45].

This process of "hiding" causation within the clause is one of recasting. As historical writing becomes more argumentative and less reliant on chronological recount, authors repackage the independent clauses that once relied upon causal connectors to create single clauses containing the same meaning. These single clauses can be further recast to complex noun phrases. Such noun phrases form the basis for grammatical metaphor, the technicalization of language within the discipline through "nouning a verb" [46].

As causation is repackaged into more compact forms, a number of things happen. First, the language used becomes less "everyday" and more "academic." Spoken language is often less condensed because it relies on context between the interlocutors and because there is little need to edit for space, as is the case with written communication [47]. "Everyday" language, then, has little need to (or want to) carefully consider the ways in which to recast the meaning of two ideas into one. Indeed, a casual conversationalist who opens with the phrase "The effect of British educational hegemony..." would be thought strange in all but the most academic of social groups.

In this shift from the everyday to the academic, meanings become more technical and less explicit. For example, a piece of academic writing may condense the two verb phrases "creating schools" and "spreading democratic ideals" into the noun phrase "political cultural hegemony." In its technical nature, this recasting loses the explicitness of the two actions but adds an "axiological charging" of terms [48], including not only information about what happened but about how one should feel about the action. In this case, cultural hegemony has a negative connotation for post-colonial readers. Again, however, this connotative valuing is only accessible to those who understand the technical language of the text. As ideas are recast for the less-informed reader, explicit happenings are obscured and technical meanings are less likely to be understood, negatively impacting such a reader's comprehension of an author's meaning.

The second thing that happens when recasting shifts 
occur is that authors use nominalizations to liberate the text from narrative chronology. Without the need to recount a narrative chronologically, genres of explanation and argument are possible. These genres rely on factorial causation to illustrate the complexity of events [49]. By focusing causation on ideas and concepts (such as "the creation of schools") rather than the more spoken, unpacked events of a situation (e.g., "they created schools"), authors are able to reach across history to wed myriad events to make a particular case. These complex histories increase the sophistication readers need to comprehend such texts [50]. In fact, the Write it Right Project demonstrated the need for explicit teacher training to recognize such causal grammar resources and to help their students to recast information in both directions of the continuum [51].

\subsubsection{Hidden Causation}

History textbooks provide a good training ground for teaching students to recognize these causal construction variations. As Fitzgerald[52] demonstrated, United States history textbooks contain all of these variations, allowing teachers to apprentice their students in comprehending and recasting cause and effect. Fitzgerald's study also illustrated the use of causal asyndetic constructions, a causal construction that does not rely on causal connectors to express causation; instead, causation is implied using mental, verbal, and relational processes in addition to modals. These constructions were used as frequently as other types of causal constructions.

\subsection{Grappling with Shifts}

In the historical thinking literature, proponents often disassociate the psychological and linguistic processes of "doing history." Sam Wineburg[53], the scholar most responsible for detailing historical thinking heuristics, has argued that teachers should "tamper" with history, making the language more accessible to students. Others [e.g., 54-56] simply neglect to discuss the lexicogrammatical shifts in the historical process. Both intentionally tampering with and intentionally neglecting to mentor students in historical language limit students' abilities to make sense of and construct history on history's terms. As linguistic work with history teachers and students demonstrates [e.g., 57-62], the more capable students are at engaging with text language in disciplinary ways, the better their comprehension. In addition, the more capable they are at using genre-specific language, the better able they are to produce disciplinarily valued texts.

Until recently, teachers have often used history textbooks as their primary instructional material [63]. These textbooks provided a mentor text to students, enabling teachers to help students read and think historically in disciplinary ways [64]. As students engage less with textbooks and more with historical primary source documents, it is important to compare these two types of instructional materials. Since causal construction is critical to comprehending [65] and composing [66] historical argument, this study will focus its comparison on that component in both PSDs and history textbooks.

\section{Materials and Methods}

This study compared passages from 4 United States history textbooks (2 middle grades and 2 high school textbooks) with content-associated, text-based primary source documents (PSDs) recommended by a university-based historical thinking group. Two questions were explored: (1) What is the difference in causal construction exposure between PSDs and textbooks? and (2) In what ways do the types of causation qualitatively vary between textbooks and primary source documents? Answers to the first question evidence the variety and number of causal constructions that teachers and students can explore in each text, making them rich for mentored reading possibilities. The second question explores the ways in which categories of causation differ between modern history textbooks and historic documents. Since some documents were written over 200 years ago, lexicogrammatical differences in causal construction may affect the ways in which teachers and students need to engage the texts.

After selecting the texts, each document was coded for examples of visible, buried, and hidden causation. Examples of visible and buried causation were drawn from Halliday and Matthiessen's[67] work. Hidden causation was drawn from Fitzgerald's[68] analysis of history textbook passages. Table 1 outlines the various causal constructions explored. Cause-conditionals represent visible causation, as they use signal words and phrases such as because, so, therefore, as a result, and for that reason. Causative, cause circumstantial, and contingency constructions represent buried causation, where verbs, prepositional phrases, and nouns are used to locate the causal construction within the clause. Causal asyndetic constructions represented hidden causation. As in Fitzgerald's[69] study, a broad "because and so" test was used to ensure that these were indeed causal constructions.

Coded frequency data was recorded in addition to the specific language used in each construction. Five independent-samples t-tests were conducted using the quantitative data exploring (1) the overall frequencies of causation in the textbooks versus the primary source documents and (2) the frequencies in each type of text within each category of causation (visible, buried, and hidden). Then, the specific passages culled from the texts were qualitatively analyzed, exploring variations in lexical markers used in the history textbooks versus the primary source documents. 
Table 1. Causal Construction Types

\begin{tabular}{|c|c|c|c|}
\hline \multirow{6}{*}{ Cause-Conditional } & General & & \\
\hline & \multirow{5}{*}{ Specific } & Result & \\
\hline & & Reason & \\
\hline & & \multirow{3}{*}{ Purpose } & Positive \\
\hline & & & Negative \\
\hline & & & Concessive \\
\hline \multicolumn{4}{|l|}{ Causative } \\
\hline \multirow[t]{3}{*}{ Cause Circumstantial } & Reason & & \\
\hline & Purpose & & \\
\hline & Behalf & & \\
\hline \multicolumn{4}{|l|}{ Expansion Clause } \\
\hline \multicolumn{4}{|l|}{ Contingency } \\
\hline \multirow{7}{*}{$\begin{array}{l}\text { Causal Asyndetic } \\
\text { Constructions }\end{array}$} & Modal & & \\
\hline & \multirow{4}{*}{ Mental } & Cognition & \\
\hline & & Emotion & \\
\hline & & Desideration & \\
\hline & & Perception & \\
\hline & Relational & & \\
\hline & Verbal & & \\
\hline
\end{tabular}

\section{Results}

A mixed-methods analysis of passages from four history textbooks and thirty-seven content-associated primary source documents demonstrated that more causal constructions occurred in the history textbook passages than in the primary source documents; these results were statistically significant. A significant difference was also found between the number of causal constructions found between the various texts, with the exception of difference between textbook passages. In addition to these differences in quantity, qualitative differences in the types of causal language used between the data sets illustrate the various constructions to which readers must attend when identifying causal constructions in each of the various text sets.

\subsection{What is the Difference in Causal Construction Exposure between PSDs and Textbooks Texts?}

While the overall frequency of causal constructions in both text sets seem small in comparison each set's word count, fluctuations in frequency percentages illustrate the relative variety of constructions in each set. As Table 2 illustrates, the percentage of various causal constructions per text-type is varied. While the percentages of causal constructions in the two sets of American Revolution texts are similar, the same constructions found in both sets of Civil War texts are quite different. The number of causal constructions found in the Civil War PSDs was much lower than the number found in the Civil War textbook passages.

To determine the potential significance of the differences between textbook and PSD passages, an independent-samples t-test was conducted to compare total causal constructions in textbook and primary source documents texts. There was a significant difference in scores for the textbook $(\mathrm{M}=73.00, \mathrm{SD}=32.49)$ and primary source document $(\mathrm{M}=4.49, \quad \mathrm{SD}=4.76)$ conditions; $\mathrm{t}(7.065)=5.95, \mathrm{p}<.001)$. These results suggest that textbooks have many more causal constructions from which students can learn than do primary source documents.

Table 2. Frequency of causal constructions per text set

\begin{tabular}{|c|c|c|c|c|c|c|c|}
\hline Text Set & $\begin{array}{l}\text { Total } \\
\text { Word } \\
\text { Count }\end{array}$ & $\begin{array}{c}\text { Total Causal } \\
\text { Constructions }\end{array}$ & $\begin{array}{c}\text { Cause } \\
\text { Conditionals }\end{array}$ & Causatives & $\begin{array}{c}\text { Cause } \\
\text { Circums-tantials }\end{array}$ & $\begin{array}{c}\text { Expansion } \\
\text { Clauses }\end{array}$ & CACs \\
\hline $\begin{array}{l}\text { American } \\
\text { Revolution } \\
\text { Textbook } \\
\text { Passages }\end{array}$ & 29,619 & $\begin{array}{c}300 \\
(1.012 \%)\end{array}$ & $\begin{array}{c}88 \\
(.297 \%)\end{array}$ & $52(.176 \%)$ & $\begin{array}{c}13 \\
(0 \%)\end{array}$ & $\begin{array}{c}28 \\
(0 \%)\end{array}$ & $\begin{array}{c}119 \\
(.402 \%)\end{array}$ \\
\hline $\begin{array}{l}\text { American } \\
\text { Revolution } \\
\text { PSDs }\end{array}$ & 10,783 & $\begin{array}{c}113 \\
(1.048 \%)\end{array}$ & $\begin{array}{c}32 \\
(.297 \%)\end{array}$ & $\begin{array}{c}22 \\
(.204 \%)\end{array}$ & $\begin{array}{c}7 \\
(0 \%)\end{array}$ & $\begin{array}{c}12 \\
(.111 \%)\end{array}$ & $\begin{array}{c}40 \\
(.371 \%)\end{array}$ \\
\hline $\begin{array}{l}\text { Civil War } \\
\text { Textbook } \\
\text { Passages }\end{array}$ & 8,091 & $\begin{array}{c}284 \\
(3.510 \%)\end{array}$ & $\begin{array}{c}67 \\
(.828 \%)\end{array}$ & $\begin{array}{c}68 \\
(.840 \%)\end{array}$ & $\begin{array}{c}30 \\
(.370 \%)\end{array}$ & $\begin{array}{c}34 \\
(.420 \%)\end{array}$ & $\begin{array}{c}85 \\
(1.051 \%)\end{array}$ \\
\hline $\begin{array}{l}\text { Civil War } \\
\text { PSDs }\end{array}$ & 25,478 & $\begin{array}{c}53 \\
(.208 \%)\end{array}$ & $\begin{array}{c}17 \\
(0 \%)\end{array}$ & $\begin{array}{c}9 \\
(0 \%)\end{array}$ & $\begin{array}{c}4 \\
(0 \%)\end{array}$ & $\begin{array}{c}3 \\
(0 \%)\end{array}$ & $\begin{array}{c}20 \\
(0 \%)\end{array}$ \\
\hline Totals & 73,971 & $\begin{array}{c}750 \\
(5.778 \%)\end{array}$ & $\begin{array}{c}204 \\
(1.422 \%) \\
\end{array}$ & $\begin{array}{c}151 \\
(1.248 \%) \\
\end{array}$ & $\begin{array}{c}54 \\
(0 \%) \\
\end{array}$ & $\begin{array}{c}77 \\
(.104 \%) \\
\end{array}$ & $\begin{array}{c}264 \\
(1.824 \%) \\
\end{array}$ \\
\hline
\end{tabular}


Additional independent-samples t-tests noted a significant effect for total causal constructions between American Revolution and Civil War PSDs [t(31.11)=1.72, $\mathrm{p}<.05)]$, between American Revolution textbook passages and American Revolution PSDs [ $\mathrm{t}(3.02)=3.53, \mathrm{p}<.05]$, and Civil War textbook passages and Civil War PSDs $[\mathrm{t}(3.02)=4.48, \mathrm{p}<.05]$. A significant difference in scores for American Revolution textbook passages $(M=75.00$, $\mathrm{SD}=39.18)$ and Civil War textbook passages $(\mathrm{M}=71$, $\mathrm{SD}=30.28)$ was not detected; $\mathrm{t}(5.64)=.162, \mathrm{p}>.05$. These results suggest that while textbook passages routinely contain more causal constructions than the primary source documents sampled, textbook passages are rather similar in the number of causal constructions they contain as a genre.

\subsection{In What Ways Do the Types of Causation Qualitatively Vary between Textbooks and Primary Source Documents Passages?}

Variations in causal constructions were assessed by exploring the constructions that occurred most frequently throughout all text sets. Four constructions were selected from the frequency data for qualitative comparison:

- cause conditional: general (e.g., because, therefore, and so),

- $\quad$ cause conditional: specific: result (e.g., as a result),

- $\quad$ causatives (e.g., make, let, force, etc.),

- causal asyndetic constructions: mental processes (e.g., those related to actors' thinking, feeling, wanting, or perceiving).

Together, these constructions accounted for approximately forty percent of the total number of causal constructions across the text sets.

\subsubsection{Cause Conditional: General}

Cause conditional: general constructions are easily identified by authors' uses of specific lexical items such as because, therefore, and so. Comparing the lexical cues across text sets, the frequency with which various lexical items are used depends on the text set. As Table 3 illustrates, history textbooks include because and so more frequently than the primary source documents (PSDs). Therefore and for are used frequently in the American Revolution PSDs and because, so, and therefore are used frequently in the Civil War PSDs. In these ways, the cause conditional: general constructions of the Civil War PSDs and the history textbooks are similar.

Because, so, and therefore comprise $89 \%$ of the cause conditional: general constructions across all sampled texts. This result is not surprising; they are the items that students are taught to identify when searching for causal connections. However, five lexical items comprise $11 \%$ of such constructions, indicating that there is some variation not accounted for by the exclusive search for because, so, and therefore.
Table 3. Variations of Cause Conditional: General Constructions

\begin{tabular}{|c|c|c|c|c|}
\hline Lexical Item & $\begin{array}{c}\text { Am Rev } \\
\text { Textbooks }\end{array}$ & $\begin{array}{c}\text { Am } \\
\text { Rev } \\
\text { PSDs }\end{array}$ & $\begin{array}{l}\text { Civil War } \\
\text { Textbooks }\end{array}$ & $\begin{array}{c}\text { Civil } \\
\text { War } \\
\text { PSDs }\end{array}$ \\
\hline Because & $32(55 \%)$ & $\begin{array}{c}2 \\
(10 \%)\end{array}$ & $36(78 \%)$ & $\begin{array}{c}4 \\
(44 \%) \\
\end{array}$ \\
\hline Consequently & & & $1(2 \%)$ & \\
\hline For & $1(1.7 \%)$ & $\begin{array}{c}6 \\
(30 \%)\end{array}$ & & $\begin{array}{c}1 \\
(11 \%) \\
\end{array}$ \\
\hline Since & $2(3.4 \%)$ & & $1(2 \%)$ & \\
\hline So & $16(27 \%)$ & $\begin{array}{c}2 \\
(10 \%)\end{array}$ & $8(18 \%)$ & $\begin{array}{c}2 \\
(22 \%) \\
\end{array}$ \\
\hline That & & $\begin{array}{c}2 \\
(10 \%)\end{array}$ & & \\
\hline Therefore & $5(8.6 \%)$ & $\begin{array}{c}8 \\
(40 \%)\end{array}$ & & $\begin{array}{c}2 \\
(22 \%)\end{array}$ \\
\hline Thus & $1(1.7 \%)$ & & & \\
\hline
\end{tabular}

The use of for within this type of causal construction deserves particular consideration amongst these less-popularly used items because it is used frequently used in the American Revolution PSDs and used some in the Civil War PSDs and American Revolution textbook passages. Used as a substitute for because, for is used to indicate an explanation for an event. Benjamin Franklin used for to explain how a particular preacher earned large donations to his church when he wrote, "Returning northward, he preached up this charity, and made large collections, for his eloquence had a wonderful power over the hearts and purses of his hearers, of which I myself was an instance." Similar uses of for were mostly found in the earliest of the documents analyzed; six of the eight instances were found in documents dating between 1740 and 1793. In comparing the use of for with because, it is interesting to note that the two instances of because found in the American Revolution PSD text set came from passages written by a modern-day historian, Kermit Hall, in 1987.

\subsubsection{Cause Conditional: Specific: Result}

Whereas authors use the lexical items so and therefore to indicate "forward causation," they also make sure of the more context-explicit cause conditional: specific: result. This more explicit form represents $21 \%$ of the cause conditional constructions instances across the text sets. By far, the phrase "as a result" was used the most frequently of this type, especially across history textbook passages; "as a result" accounted for $46 \%$ and $79 \%$ of the cause conditional: specific: result instances in the American Revolution and Civil War textbook passages, respectively. No other single phrase exceeded more than $8 \%$ of any one text set's use of this construction. Numbers of this construction were very low across the primary source document text sets.

While there is little variation in the ways that this particular construction is expressed, there are differences in the positioning of these phrases per text type. $96 \%$ of the cause conditional: specific: result phrases in the American 
Revolution textbook text set were positioned at the beginning of the sentence; $79 \%$ of the same construction were placed at the beginning of the Civil War textbook text set. However, only $50 \%$ of similar phrases were used at the beginning of sentences in the American Revolution PSD text set. This difference demonstrates a difference in where a reader might expect to find this particular construction.

\subsubsection{Causatives}

There were quite a few instances of causative use, especially since they were coded as a single category unto themselves. The causatives found across the text sets were also varied, with 30 lexical verbs across 145 instances. Across these lexical verbs, 9 stand out as high frequency items, comprising $10 \%$ or more of the causatives used in a given text set (see Table 4).

Table 4. High frequency causatives per text set

\begin{tabular}{|c|c|c|c|}
\hline Am Rev & Am Rev & Civil War & Civil War \\
Textbooks & PSDs & Textbooks & PSDs \\
\hline Force (17) & Make (9) & Force (18) & Compel (3) \\
$35 \%$ & $41 \%$ & $27 \%$ & $33 \%$ \\
\hline Lead (11) & Prevent (3) & Cause (16) & Force (2) \\
$23 \%$ & $13 \%$ & $24 \%$ & $22 \%$ \\
\hline & & Lead (12) & Cause (1) \\
& & $18 \%$ & $11 \%$ \\
\hline & & Make (10) & Induce (1) \\
& & $15 \%$ & $11 \%$ \\
\hline & & & Make (1) \\
& & & $11 \%$ \\
\hline & & & Prohibit (1) \\
& & & $11 \%$ \\
\hline
\end{tabular}

Some of these causatives are tied closely to the content of the text. Processes such as to force and to lead are related in part to the types of military situations described in these texts. Still others seem more global, such as to make and to cause. It is interesting to note that most of these high frequency causatives are positive; only prevent and prohibit have negative polarity. These two examples also come from the primary source documents. No causatives with negative polarity were found in the history textbook passages.

\subsubsection{Casual Asyndetic Constructions: Mental Processes}

Casual asyndetic constructions (CACs), as a whole, represent an important portion of the overall causal constructions across the text sets. Of the CACs, mental processes are the most numerous, accounting for $55 \%$ of the all identified CACs. Across the four sub-processes of cognition, emotion, desideration, and perception, the types of mental processes were similar, as illustrated in Table 5, which notes mental processes that occurred in $10 \%$ or more of a given set.

Across the text sets, the predominant emotional responses that indicate causation are negative (e.g., fear, rage, outrage). More positive mental processes are aligned with cognition (e.g., believe) and desideration (e.g., aim and hope). As these latter processes were used to convey belief and hope in a physical situation such as troop movements and time and were not used in spiritual terms, they were not categorized as emotional processes. These similarities in both lexical items and their polarities across text sets demonstrate a stable repository of mental process use across text types for form CACs.

Table 5. Types of Mental Processes per Text Set

\begin{tabular}{|c|c|c|c|c|}
\hline Mental Process & Am Rev Textbook & Am Rev PSD & Civil War Textbook & Civil War PSD \\
\hline Cognition & $\begin{array}{c}\text { Believe }(25 \%) \\
\text { Decide }(32 \%) \\
\text { Know }(14 \%) \\
\text { Think }(18 \%)\end{array}$ & $\begin{array}{c}\text { Suspect }(50 \%) \\
\text { Know }(50 \%)\end{array}$ & $\begin{array}{c}\text { Believe }(32 \%) \\
\text { Decide }(16 \%) \\
\text { Know }(16 \%)\end{array}$ & \\
\hline Emotion & $\begin{array}{c}\text { Anger (10\%) } \\
\text { Encourage }(10 \%) \\
\text { Fear }(30 \%) \\
\text { Feel }(10 \%) \\
\text { Outrage }(15 \%)\end{array}$ & $\begin{array}{l}\text { Alarm }(33 \%) \\
\text { Regret }(33 \%) \\
\text { Resent }(33 \%)\end{array}$ & $\begin{array}{c}\text { Fear }(20 \%) \\
\text { Frustrate }(10 \%) \\
\text { Fury }(10 \%) \\
\text { Tire }(20 \%) \\
\text { Rage }(20 \%) \\
\text { Resent }(20 \%)\end{array}$ & \\
\hline Desideration & $\begin{array}{l}\text { Hope }(33 \%) \\
\text { Want }(47 \%)\end{array}$ & $\begin{array}{l}\text { Want }(50 \%) \\
\text { Wish }(50 \%)\end{array}$ & $\begin{array}{l}\text { Hope }(27 \%) \\
\text { Want }(36 \%) \\
\end{array}$ & \\
\hline Perception & $\begin{array}{c}\text { Listen }(20 \%) \\
\text { Look }(20 \%) \\
\text { See }(20 \%) \\
\text { Show }(40 \%)\end{array}$ & Murmur (100\%) & See $(100 \%)$ & \\
\hline
\end{tabular}




\section{Discussion}

This study examined the causal constructions found in popular history textbooks and primary source documents, both used for instructional purposes. The results demonstrate that the number and types of causal constructions vary between PSDs and the textbook passages. These differences contribute to the growing body of literature exploring considerations for apprenticing students in reading and writing history [e.g., 70-80] by verifying that the causal constructions between each text set vary by a significant amount. This difference means that students are not exposed to the same number of causal constructions while reading PSDs as they are when they read history textbooks. Moreover, the causal constructions students read as part of their historical inquiries differ in kind with those they are expected to construct as historical argument. These results have implications for the ways in which teachers apprentice history students' learning as they engage in historical thinking activities: (1) the ways that teachers engage historical language variations as part of the close reading process and (2) the ways that both textbooks and PSDs can be used during the writing process.

\subsection{Language Variations and Close Reading}

Wineburg[ $[81,82]$ found that historians conduct a close reading of any source they engage, trying to understand the what, why, and how of the document. Implicit in his findings was a realization that the language used in the past might not mean what it means today. This study demonstrates a need for teachers to model an appreciation for language variations during this process as they apprentice students to engage close reading activities.

For example, early colonial PSDs used as part of this study used the cause conditional: general item for instead of because. If teachers suggest that students look for the words because and so to recognize causal connections as the literature [e.g., 83] suggests that they do, students may miss the cues used in these historical documents. To be sure, this is a simple substitution for many students, one that they may be familiar with due to the less-frequent use of for as because in modern English. However, the principle of closely examining language in such a way is important to helping students comprehend historical texts.

Such variations are not only lexical but syntactical as well. Cause Conditional: Specific: Result constructions appear at the beginning of many textbook sentences but in the middle of many sentences in the primary source documents. This shift in position forces readers to grapple with more complex sentence structures and use more working memory to comprehend text. Alerting students to such syntactic variation prior to examining a text allows students to comprehend such structures more readily, improving reading fluency and comprehension.

\subsection{Using PSDs and Textbooks as Instructional Materials}

The variations in number and kind of causal constructions across text sets support the joint use of PSDs and historical works (possibly textbooks) during history instruction. While the former comprise the "raw materials" of history, the latter is an example of written history, even if it is not of the highest quality. History textbooks use causal constructions differently than PSDs by virtue of the historical synthesis that occurs to create the text. Critically evaluating textbooks via historical thinking heuristics [84], teachers can apprentice students to both think about textbooks as constructed history with an argument and think about the constructions that were created as a transformation from reading PSDs.

Given the topical and chronological similarities between the ways that history textbooks and PSD resource sites structure content, teachers could use the PSDs for particular units of instruction to evaluate textbook claims. Since textbooks rarely cite their sources, students could examine relevant PSDs in light of assessing a textbook's narrative. In this way, students are exposed to historical writing via the textbook and apprenticed in historical thinking via the PSDs. Extension activities could include revising the textbook by including PSD-related footnotes, writing complementary textbook passages based on PSD information, or debating historical claims using both sources of information.

\section{Conclusions}

As teachers increasingly integrate reading historical primary source documents into their instruction and ask students to craft argument from such sources, it is important to apprentice students to recognize and transform causal connections in PSDs to inform their historical writing. This study demonstrates that there are differences between the number and kind of causal constructions found in PSDs and history textbooks. Using both during instruction and guiding students to comprehend the former and use appropriate constructions to express the latter will benefit students' historical thinking comprehension and writing.

\section{REFERENCES}

[1] Apple MW. Regulating the text: The socio-historical roots of state control. In: Altbach PG, Kelly GP, Petrie HG, Weis L, editors. Textbooks in American society: Politics, policy, and pedagogy. Albany, New York: State University of New York Press; 1991. 
[2] FitzGerald F. America revised. Boston: Little, Brown and Company; 1979.

[3] Kincheloe JL. Getting beyond the facts: teaching social studies/social sciences in the twenty-first century. New York: Peter Lang; 2001. 818 p. (Counterpoints; vol. 2nd).

[4] Loewen JW. Lies my teacher told me: Everything your american history textbook got wrong. New York: Touchstone; 1995.

[5] Levstik LS, Barton KC. Doing history: Investigating with children in elementary and middle schools. Vol. 2nd. Mahwah, NJ: Lawrence Erlbaum Associates; 2001.

[6] Seixas P. The community of inquiry as a basis for knowledge and learning: The case of history. Am Educ Res J. 1993;30(2):305-24

[7] VanSledright B. In search of America's past. New York: Teachers College Press; 2002.

[8] Wineburg S. Historical thinking and other unnatural acts. Philadelphia: Temple University Press; 2001.

[9] Jewett S, Ackerman AT. "A time machine to the past": Using primary sources in the social studies classroom. In: Passe J, Fitchett PG, editors. The status of social studies: Views from the field. Charlotte, N.C.: Information Age Publishing, Inc.; 2013. p. 211-32.

[10] De La Paz S, Monte-Sano C, Felton M, Croninger R, Jackson C, Piantedosi KW. A historical writing apprenticeship for adolescents: Integrating disciplinary learning with cognitive strategies. Read Res Q. 2016;52(1):31-52.

[11] Humphrey S. Academic literacies in the middle years. New York, NY: Routledge; 2017.

[12] Bernstein B. Pedagogy, symbolic control and identity: Theory, research, critique. London, UK: Routledge \& Kegan Paul; 1996.

[13] Evans RW. Social studies wars: What should we teacher the children? New York: Teachers College Press; 2004.

[14] Leinhardt G. Instructional explanations: A commonplace for teaching and location for contrast. In: Richardson V, editor. Handbook of research on teaching. Washington, D.C.: American Educational Research Association; 2001. p. 4th ed., 333-57.

[15] Maton K, Hood S, Shay S, editors. Knowledge-building: Educational studies in legitimation code theory. New York, NY: Routledge; 2017.

[16] Coffin C. Historical discourse: The language of time, cause and evaluation. Hyland K, editor. London: Continuum; 2006. (Continuum Discourse Series).

[17] Levesque S. Thinking historically: Educating students for the twenty-first century. Toronto: University of Toronto Press; 2008.

[18] Committee of Seven. The study of history in schools: Report to the American historical association. New York: The Macmillan Company; 1899.

[19] National Education Association. Report of the Committee of Ten on secondary school studies. New York: The American
Book Company; 1894.

[20] Evans RW. Social studies wars: What should we teacher the children? New York: Teachers College Press; 2004.

[21] Nash GB, Crabtree C, Dunn RE. History on trial: Culture wars and the teaching of the past. New York, NY: Random House; 1997.

[22] Wineburg S. Historical problem solving: A study of the cognitive processes used in the evaluation of documentary and pictorial evidence. J Educ Psychol. 1991;83(1):73-87.

[23] Wineburg S. Historical thinking and other unnatural acts. Philadelphia: Temple University Press; 2001.

[24] Croddy M, Levine P. The C3 framework: A powerful tool for preparing future generations for informed and engaged civic life. Soc Educ. 2014;78(6):282-5.

[25] Grant SG, Swan K, Lee J. Bringing the C3 Framework to life. Soc Educ. 2015;79(5):310-215.

[26] National Council for the Social Studies. College, Career, and Civic Life (C3) Framework for Social Studies State Standards [Internet]. National Council for the Social Studies. [cited 2014 Sep 26]. Available from: http://www.socialstudies.org/c3

[27] Monte-Sano C, De La Paz S, Felton M. Reading, thinking, and writing about history. New York, NY: Teachers College Press; 2014. (The Common Core State Standards in Literacy Series).

[28] Nokes JD. Preparing novice history teachers to meet students' literacy needs. Read Psychol. 2010;31(6):493523.

[29] Nokes JD. Recognizing and addressing the barriers to adolescents' "reading like historians." Hist Teach. 2011;44(3):379-404.

[30] Nokes JD. Building students' historical literacies: Learning to read and reason with historical texts and evidence. New York, NY: Routledge; 2013.

[31] Miller RT, Mitchell TD, Pessoa S. Valued voices: Students' use of engagement in argumentative history writing. Linguist Educ. 2014;28:107-20.

[32] Miller RT, Mitchell TD, Pessoa S. Impact of source texts and prompts on students' genre uptake. J Second Lang Writ. 2016;31:11-24

[33] Martin J, Maton K, Matruglio E. Historical cosmologies: Epistemology and axiology in Australian secondary school history discourse. Rev Signos. 2010;43(74):433-63.

[34] Coffin C. Learning to write history: The role of causality. Writ Commun. 2004;21(3):261-89.

[35] Coffin C. Historical discourse: The language of time, cause and evaluation. Hyland K, editor. London: Continuum; 2006. (Continuum Discourse Series).

[36] Veel R, Coffin C. Learning to think like an historian: the language of secondary school history. In: Hasan R, Williams G, editors. Literacy in society. New York: Addison Wesley Longman; 1996. p. 191-231.

[37] Christie F, Martin JR. Language, knowledge and pedagogy: Functional linguistic and sociological perspectives. London, 
UK: Continuum; 2007.

[38] Christie F, Maton K, editors. Disciplinarity: Functional linguistic and sociological perspectives [Internet]. London, UK: Continuum International Publishing; 2011 [cited 2017 Jun 14]. Available from: http://www.bloomsbury.com/us/di sciplinarity-functional-linguistic-and-sociological-perspecti ves-9781441131805/

[39] Fitzgerald JC. An analysis of causal asyndetic constructions in United States history textbooks. Funct Linguist. 2014;1(5).

[40] Humphrey S. Academic literacies in the middle years. New York, NY: Routledge; 2017.

[41] Martin JR. Technicality and abstraction: Language for the creation of specialized texts. In: Christie F, editor. Writing in schools. Geelong, Victoria: Deakin University Press; 1989. p. 36-44.

[42] Bernstein B. Pedagogy, symbolic control and identity: Theory, research, critique. London, UK: Routledge \& Kegan Paul; 1996.

[43] Meyer B, Poon L. Effects of structure strategy training and signaling on recall of text. J Educ Psychol. 2001 Mar;93(1):141-59.

[44] Williams JP, Nubla-Kung AM, Pollini S, Stafford KB, Garcia A, Snyder AE. Teaching cause-effect text structure through social studies content to at-risk second graders. J Learn Disabil. 2007;40(2):111-20.

[45] Humphrey S. Academic literacies in the middle years. New York, NY: Routledge; 2017.

[46] Martin JR. Technicality and abstraction: Language for the creation of specialized texts. In: Christie F, editor. Writing in schools. Geelong, Victoria: Deakin University Press; 1989. p. $36-44$.

[47] Halliday MAK, Matthiessen CMIM. An introduction to functional grammar. Vol. 3. London: Hodder Education; 2004.

[48] Martin J, Maton K, Matruglio E. Historical cosmologies: Epistemology and axiology in Australian secondary school history discourse. Rev Signos. 2010;43(74):433-63.

[49] Coffin C. Historical discourse: The language of time, cause and evaluation. Hyland K, editor. London: Continuum; 2006. (Continuum Discourse Series).

[50] Beck IL, McKeown MG, Gromoll EW. Learning from social studies texts. Cogn Instr. 1989;6(2):99-158.

[51] Humphrey S. Academic literacies in the middle years. New York, NY: Routledge; 2017.

[52] Fitzgerald JC. An analysis of causal asyndetic constructions in United States history textbooks. Funct Linguist. 2014;1(5).

[53] Wineburg S. Historical problem solving: A study of the cognitive processes used in the evaluation of documentary and pictorial evidence. J Educ Psychol. 1991;83(1):73-87.

[54] Monte-Sano C, De La Paz S, Felton M. Reading, thinking, and writing about history. New York, NY: Teachers College Press; 2014. (The Common Core State Standards in Literacy
Series).

[55] Nokes JD. Recognizing and addressing the barriers to adolescents' "reading like historians." Hist Teach. 2011;44(3):379-404.

[56] Nokes JD. Building students' historical literacies: Learning to read and reason with historical texts and evidence. New York, NY: Routledge; 2013.

[57] Achugar M, Schleppegrell MJ. Beyond connectors: The construction of cause in history textbooks. Linguist Educ. 2005;16:298-318.

[58] Achugar M, Stainton C. Learning history and learning language: Focusing on language in historical explanations to support English language learners. In: Stein MK, Kucan L, editors. Instructional explanations in the disciplines. New York, NY: Springer; 2010. p. 145-69.

[59] Fitzgerald JC. "It doesn't say": Exploring students' understandings of asyndetic constructions in history textbooks. Soc Stud Res Pract. 2012;7(3).

[60] Humphrey S. Academic literacies in the middle years. New York, NY: Routledge; 2017.

[61] Schleppegrell M, Achugar M. Learning language and learning history: A functional linguistics approach. TESOL J. 2003;12(2):21-7.

[62] Schleppegrell M, Achugar M, Oteiza T. The grammar of history: Enhancing content-based instruction through a functional focus on language. TESOL Q. 2004;38(1):67-93.

[63] Moreau J. Schoolbook nation: Conflicts over America history textbooks from the Civil War to the present. Ann Arbor, Michigan: The University of Michigan Press; 2004.

[64] Fitzgerald JC. Textbooks and primary source analysis. Soc Stud Res Pract. 2009;4(3).

[65] Fitzgerald JC. "It doesn't say": Exploring students' understandings of asyndetic constructions in history textbooks. Soc Stud Res Pract. 2012;7(3).

[66] Coffin C. Learning to write history: The role of causality. Writ Commun. 2004;21(3):261-89.

[67] Halliday MAK, Matthiessen CMIM. An introduction to functional grammar. Vol. 3. London: Hodder Education; 2004.

[68] Fitzgerald JC. An analysis of causal asyndetic constructions in United States history textbooks. Funct Linguist. 2014;1(5).

[69] Fitzgerald JC. An analysis of causal asyndetic constructions in United States history textbooks. Funct Linguist. 2014;1(5).

[70] De La Paz S, Felton M, Monte-Sano C, Croninger R, Jackson C, Deogracias JS, et al. Developing historical reading and writing with adolescent readers: Effects on student learning. Theory Res Soc Educ. 2014;42(2):228-74.

[71] De La Paz S, Ferretti R, Wissinger D, Yee L, MacArthur C. Adolescents' disciplinary use of evidence, argumentative strategies, and organizational structure in writing about historical controversies. Writ Commun. 2012;29(4):412-54.

[72] De La Paz S, Monte-Sano C, Felton M, Croninger R, 
Jackson C, Piantedosi KW. A historical writing apprenticeship for adolescents: Integrating disciplinary learning with cognitive strategies. Read Res Q. 2016;52(1):31-52.

[73] Monte-Sano C, De La Paz S, Felton M. Reading, thinking, and writing about history. New York, NY: Teachers College Press; 2014. (The Common Core State Standards in Literacy Series).

[74] Nokes JD. Observing history teachers' literacy related decisions. 2010

[75] Nokes JD. Observing history teachers' literacy related decisions. 2010

[76] Nokes JD. Recognizing and addressing the barriers to adolescents" "reading like historians." Hist Teach. 2011;44(3):379-404.

[77] Nokes JD. Building students' historical literacies: Learning to read and reason with historical texts and evidence. New York, NY: Routledge; 2013.

[78] Nokes JD, Dole JA, Hacker DJ. Teaching high school students to use heuristics while reading historical texts. J Educ Psychol. 2007;99(3):492-504.

[79] Wineburg S. Historical thinking and other unnatural acts. Philadelphia: Temple University Press; 2001.

[80] Wineburg S. Tampering with history: Adapting primary sources for struggling readers. Soc Educ. 2009;73(5):212-6.

[81] Wineburg S. Historical thinking and other unnatural acts. Philadelphia: Temple University Press; 2001.

[82] Wineburg SS. Historical problem solving: A study of the cognitive processes used in the evaluation of documentary and pictorial evidence. J Educ Psychol. 1991 Mar;83(1):7387.

[83] Williams JP, Nubla-Kung AM, Pollini S, Stafford KB, Garcia A, Snyder AE. Teaching cause-effect text structure through social studies content to at-risk second graders. J Learn Disabil. 2007;40(2):111-20.

[84] Fitzgerald JC. Textbooks and primary source analysis. Soc Stud Res Pract. 2009;4(3). 